\title{
Biomass and nutrient composition of Spirulina platensis grown in goat manure media
}

Tatang Sopandi*, Siti Rohmah, Siti Aminullo Tri Agustina

Study Program of Biology, Faculty of Mathematical and Natural Science, University of PGRI Adi Buana, Surabaya, East Java, Indonesia

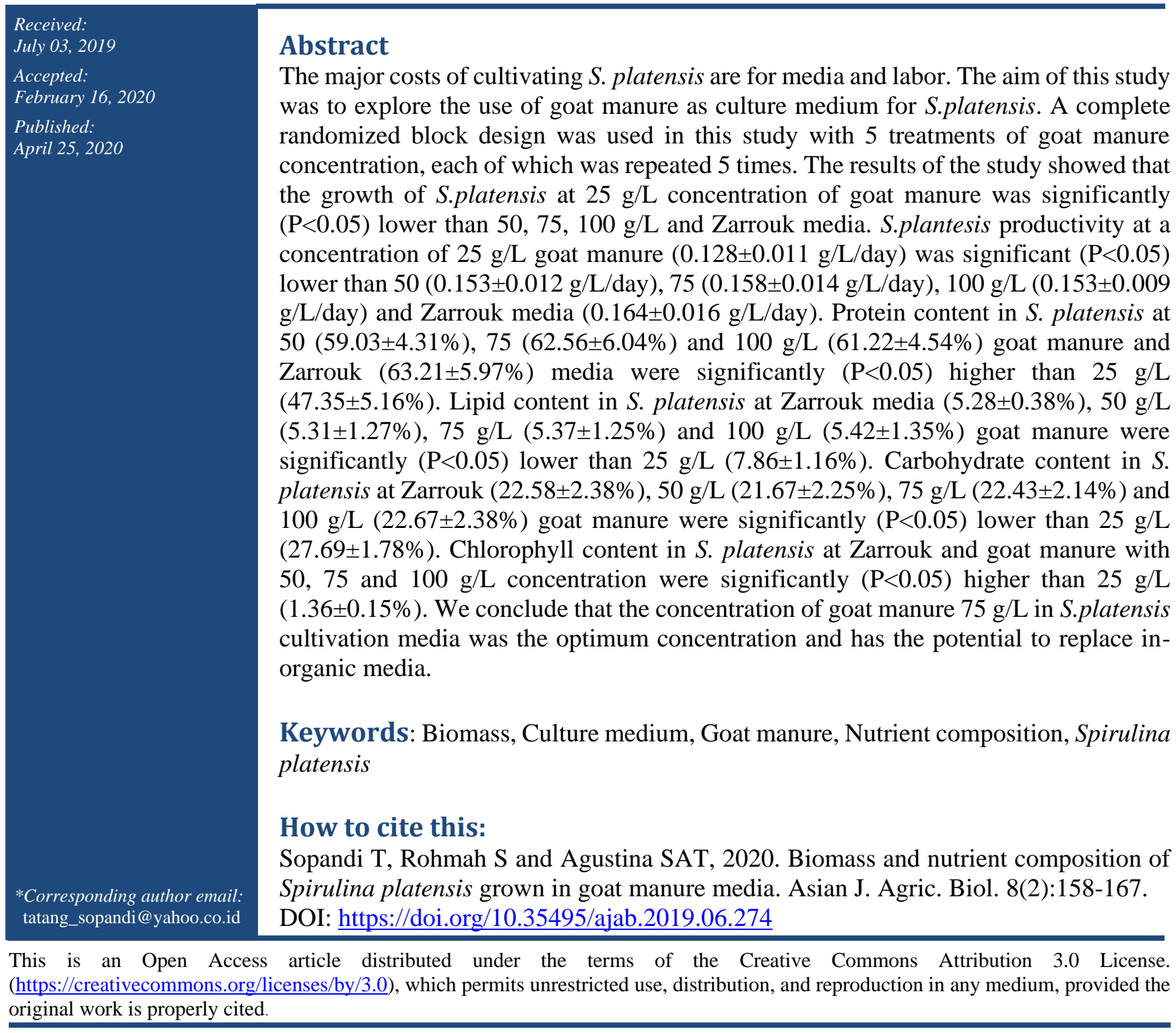




\section{Introduction}

Spirulina platensis has the potential to be commercially produced and used as food and animal feed (Holman and Malau-Aduli, 2013; Muhling et al., 2005) because it is rich in protein, fat, carbohydrates and other important elements (Kerswell, 2006; Sherwood et al., 2010; Sánchez et al., 2003) such as chlorophyll (Moraes et al., 2011) and amino acids (Avila-Leon et al., 2012). High phytonutrient content in S. platensis biomass such as phycocyanin, carotene, xanthophyll, gamma linoleic acid, galactolipids, sulpholipids, chlorophyll, and minerals which have beneficial effects on human health such as antioxidation (Pleonsil et al., 2013), anti-cancer (Thangam et al., 2013), anti-inflammatory activity (Zhu et al., 2016), photo-induced cytotoxicity (Wang et al., 2012), stimulation of the immune system ( $\mathrm{Li}$ et al., 2010), anti-malnutrition, anti-anemia, anti-oxidative, antiviral and anti-cancer properties (Estrada et al., 2001; Belay, 2002; Sánchez et al., 2003) attract market interest in the food industry. Nutrient content in $S$. platensis biomass has also attracted market interest in the animal feed industry, even Holman and MalauAduli (2013) reported that half of biomass production was used for livestock feed and fish.

S. platensis has high adaptability and can be cultivated in various nutrient conditions. Generally, large-scale S. platensis cultivation used Zarrouk and Walne media as a source of nutrition. The both in-organic media are relatively complex, expensive and with limited availability. The main production costs for $S$. platensis cultivation are media and labor. The search for $S$. platensis cultivation media with lower cost and sufficient availability is conducted to minimize production costs and increase revenue. Some investigators have reported the replacement of several elements contained in the Walne and Zarrouk media. Organic matter (Andrade and Costa, 2009) and wastewater (Mezzomo et al., 2010) were reported to be used as a source of nutrition in $S$. platensis cultivation media.

Livestock by-product is a potential source of nutrition for microalgae cultivation media and plant fertilizer. Goat manure is a livestock by-product that is quite abundant, especially in Indonesia but is not used conventionally as culture medium for $S$. platensis. Indonesian farmers generally use goat manure as growing media for plant. Goat manure contains $4.9 \%$ total nitrogen, $4.1 \%$ phosphorus, $1.9 \%$ potassium, $1.0 \%$ calcium, and $0.9 \%$ magnesium (Awodun et al.,
2007) and has been studied to be used as a nutrient source for Chlorella microalgae cultivation media (Kinosraj et al., 2016; Agwa et al., 2012). Danmaigoro et al., (2019) reported that poultry manure had a significant effect on rice growth and yield. Awodun et al., (2007) reported that goat manure had a significant increase on pepper growth and yield parameters as number of leaves and branches, plant height, stem girth, number and weight of fruits. Livestock byproduct such as pig manure (Canizares et al., 1994; Olguin et al., 2001) and chickens manure (Iyoyo et al., 2010) has been reported as low-cost nitrogen sources for microalgae cultivation. However, information regarding the utilization of goat manure as a $S$. platensis cultivation medium is limited. The present study aims to explore the use of goat manure as a $S$. platensis cultivation medium.

\section{Material and Methods}

This study has been carried out at the Laboratory of Biology, Study Program of Biology, Faculty of Mathematics and Natural Sciences, University of PGRI Adi Buana Surabaya. A completely randomized block design with 4 concentrations of goat manure in S. platensis medium follows A (25 g/L), B (50 g/L), C $(75 \mathrm{~g} / \mathrm{L})$ and $\mathrm{D}(100 \mathrm{~g} / \mathrm{L})$ and Zarrouk media was use as a control. All treatments in this study were repeated 5 times.

\section{Preparation of goat manure}

Goat manure was obtained from local farmers in Sidoarjo, Indonesia. A total of $2500 \mathrm{~g}$ of goat manure was dried in the sun for 2 days and milled using mechanical grinder to obtain goat manure powder.

\section{Cultivation of $S$. platensis}

A total of $500 \mathrm{~g}$ of goat manure powder is divided into 4 parts, 50, 100, 150 and $200 \mathrm{~g}$, respectively. Each part was dissolved in $20 \mathrm{~L}$ of tap water, stirred and filtered by Whatman paper No. 42 to obtain the concentration of goat manure $25,50,75$ and $100 \mathrm{~g} / \mathrm{L}$. To the filtrates $0.2 \% \mathrm{NaCl}$ was added and $\mathrm{pH}$ was adjusted to 10 with $\mathrm{NaHCO}_{3}$ and the solution was stirred until homogeneous. In the present study, we have used the media of Zarrouk (Zarrouk, 1966) as a control cultivation media with 5 replications. All media were sterilized at $121^{\circ} \mathrm{C}$ for 15 minutes and after being cooled in the room until the temperature reached $24^{\circ} \mathrm{C}$, $0.25 \mathrm{~L}$ of $\mathrm{S}$. platensis brood stock was inoculated into each $1 \mathrm{~L}$ of media. Cultivation of $S$. platensis was 
carried out for 14 days in an Erlenmeyer flask (1500 $\mathrm{mL}$ ) at $25-35^{\circ} \mathrm{C}$, salinity $30-70 \mathrm{ppt}, \mathrm{pH}$ 9.0-9.5, light intensity 5000 lux (Benetech GM 1020 illuminance meter) and agitation at $60 \mathrm{rpm}$ in the shaker (Gesellschaft fur Labortechnik, Germany).

\section{Assays of chemical composition of goat manure media}

The assays for chemical composition of the goat manure media included total organic carbon, nitrate and phosphorus was carried out before $S$. platensis inoculation. The content of total organic carbon (TOC) in the $S$. platensis biomass was analyzed using the wet oxidation method guided by Walkey and Black (1965). The level of nitrate $\left(\mathrm{NO}_{3}-\mathrm{N}\right)$ analysis was done using the method of spectrophotometer at $410 \mathrm{~nm}$. The spectrophotometer method has been carried out to determine the phosphorus content in $S$. platensis biomass.

\section{Biomass $S$. platensis}

The method of Yap et al. (2018) used a spectrophotometer (Thermo Fisher Scientific, Genesis 20, USA) at a wavelength of $680 \mathrm{~nm}$ and was repeated 3 times to be used to observe the development of daily S. platensis biomass. One milliliterof Spirulina culture was took out every day for the OD 680 measurement. The biomass daily Spirulina was analyzed using regression analysis as the Spirulina biomass is 0.8274 optical density value plus 0.0393 . The standard curve has been made by diluting a series of $1.6 \mathrm{~g} / \mathrm{L}$ of Spirulina dry biomass and was subsequently used to calculate the biomass of individual samples. At the 14 days cultivation Spirulina was harvested by filtration through synthetic fiber cloth with a mesh size of 50 microns to separate the biomass of Spirulina from the liquid culture, washed by fresh water followed by filtration using a mesh size of 200 microns to remove any salt from the culture medium. The filters with the Spirulina cells were dried at $80^{\circ} \mathrm{C}$ in an oven overnight. Analysis of the composition biomass of $S$. platensis including protein, lipid, carbohydrate and chlorophyll contents were carried out.

\section{Assays the biomass of $S$. platensis nutrient composition}

Nutrient composition in $S$. platensis biomass was analyzed for proximate composition in accordance with Association of Official Analytical Chemists (AOAC, 1990) recommendations consists of crude protein, crude fat and carbohydrates. Chlorophyll-a content in the biomass of $S$. platensis was determined by the method of Jeffrey and Humphrey (1975).

\section{Results and Discussion}

In this study, some minerals content in goat manure consisted of $531.42 \mathrm{~g} / \mathrm{kg}$ of total carbon, $3.78 \mathrm{~g} / \mathrm{kg}$ of total nitrogen, $1.76 \mathrm{~g} / \mathrm{kg}$ of phosphorus and $0.52 \mathrm{~g} / \mathrm{kg}$ of potassium. Some previous investigators have reported the different chemical composition of goat manure (Mnkeni and Austin; 2009; Tennakoon and Bandara, 2003: Omisore et al., 2018). Variations in the chemical composition of goat manure can be due to diet, age, weight sex (Powell et al., 1994), type of livestock, growth and feeding practices, weather, and storage time and conditions (Smith and Frost, 2000) . Some of the mineral content of goat manure in this study is presented in table 1 . The concentration of goat manure in cultivation media can affect mineral content such as total carbon, total nitrogen, phosphorus and potassium $S$. platensis. The mineral content (total carbon, total nitrogen, phosphorus and potassium) in S. platensis cultivation media with goat manure concentrations 25, 50, 75 and $100 \mathrm{~g} / \mathrm{L}$ was significantly $(\mathrm{P}<0.05)$ different from each other.

Table-1: Some minerals content in goat manure culture media for $S$. platensis.

\begin{tabular}{|c|c|c|c|c|c|}
\hline $\begin{array}{c}\text { Concentration } \\
\text { of goat manure } \\
\text { in media }(\mathrm{g} / \mathrm{L})\end{array}$ & \multicolumn{5}{|c|}{ Element } \\
\hline & $\begin{array}{c}\text { Total carbon } \\
(\mathrm{g} / \mathrm{L})\end{array}$ & $\begin{array}{c}\text { Total nitrogen } \\
(\mathrm{g} / \mathrm{L})\end{array}$ & $\begin{array}{c}\text { Nitrate } \\
(\mathrm{mg} / \mathrm{L})\end{array}$ & $\begin{array}{c}\text { Phosphorus } \\
(\mathrm{g} / \mathrm{L})\end{array}$ & $\begin{array}{c}\text { Potassium } \\
(\mathrm{g} / \mathrm{L})\end{array}$ \\
\hline 25 & $13.29 \pm 4.65^{\mathrm{a}}$ & $0.87 \pm 0.13^{\mathrm{a}}$ & $5.22 \pm 2.04^{\mathrm{a}}$ & $0.34 \pm 0.09^{\mathrm{a}}$ & $0.13 \pm 0.03^{\mathrm{a}}$ \\
\hline 50 & $25.57 \pm 9.72^{\mathrm{b}}$ & $1.24 \pm 0.32^{\mathrm{b}}$ & $10.81 \pm 4.23^{\mathrm{b}}$ & $0.72 \pm 0.17^{\mathrm{b}}$ & $0.29 \pm 0.08^{\mathrm{b}}$ \\
\hline 75 & $40.86 \pm 12.26^{\mathrm{c}}$ & $2.56 \pm 0.45^{\mathrm{c}}$ & $15.66 \pm 6.13^{\mathrm{c}}$ & $0.92 \pm 0.29^{\mathrm{c}}$ & $0.42 \pm 0.09^{\mathrm{c}}$ \\
\hline 100 & $52.79 \pm 19.14^{\mathrm{d}}$ & $3.87 \pm 0.78^{\mathrm{d}}$ & $31.82 \pm 12.46^{\mathrm{d}}$ & $1.23 \pm 0.42^{\mathrm{d}}$ & $0.69 \pm 0.21^{\mathrm{d}}$ \\
\hline
\end{tabular}

The values and standard deviation $( \pm)$ with different superscripts $\left({ }^{\mathrm{a}},{ }^{\mathrm{b}},{ }^{\mathrm{c}}\right.$ and $\left.{ }^{\mathrm{d}}\right)$ in same column are different significant $(\mathrm{P}<0.05)$.

\section{Biomass of $S$. platensis}

The response of $S$. platensis daily biomass to Zarrouk and goat manure media in this study is presented in Figure 1. As shown in Figure 1, the rate of increase in S. platensis biomass in all media during the first 7 days was almost similar. But on day 8 to day 14 cultivation, the rate of increase in $S$. platensis biomass from medium $25 \mathrm{~g} / \mathrm{L}$ goat manure was lower than Zarrouk, 50,75 and $100 \mathrm{~g} / \mathrm{L}$ goat manure media. The decreasing rate of $S$. platensis biomass is thought to be due to the depletion of nutrient availability and the increase of $S$. 
platensis cell mass, especially in the medium of $25 \mathrm{~g} / \mathrm{L}$ goat manure. The slowing down of the rate of increase in $S$. platensis biomass for all media in this study occurred on the $12^{\text {th }}$ day of cultivation. As shown in table 2, the productivity of $S$. platensis during the first week of cultivation did not different significantly $(\mathrm{P}>0.05)$ in all experimental media. But in the second week of cultivation, the productivity of $S$. platensis in the medium $25 \mathrm{~g} / \mathrm{L}$ goat manure was significantly $(\mathrm{P}<0.05)$ lower than Zarrouk, 50, 75 and $100 \mathrm{~g} / \mathrm{L}$.

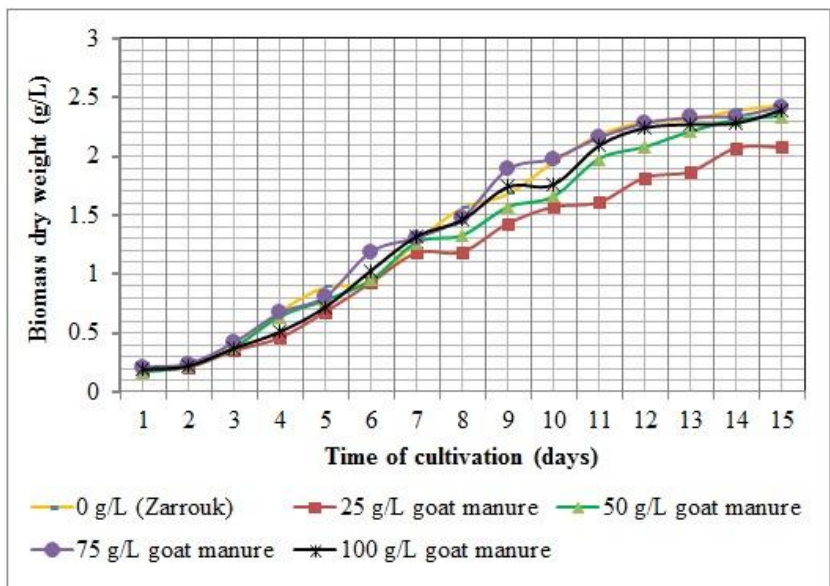

Figure-1: Curve of $S$. platensis daily biomass in Zarrouk and goat manure media

Referring to the results of analysis of some mineral content in goat manure media (table 1), the low concentrations of nitrogen especially nitrate and phosphorus may be the cause of lower biomass and $S$. platensis productivity from goat manure $25 \mathrm{~g} / \mathrm{L}$ than other cultivations media in this study. As shown in table 1, the content of nitrogen, nitrate and phosphorus in the medium $25 \mathrm{~g} / \mathrm{L}$ goat manure were $0.87 \pm 0.13$ $\mathrm{g} / \mathrm{L}, 5.22 \pm 2.04 \mathrm{mg} / \mathrm{L}$ and $0.34 \pm 0.09 \mathrm{~g} / \mathrm{L}$, respectively. Several investigators reported that the growth and productivity of $S$. platensis was determined by phosphorus concentration in cultivation media (Xin et al., 2010; Dammak et al., 2017). Markou et al. (2012) reported that the optimum productivity of spirulina biomass was obtained at a $250 \mathrm{mg} / \mathrm{L}$ phosphate concentration in the form of $\mathrm{K}_{2} \mathrm{HPO}_{4}$. Meanwhile, nitrogen plays a role in the formation of macromolecules and cell biomass (Perez-Garcia et al., 2011). Nitrogen concentration of $2.5 \mathrm{~g} / \mathrm{L}$ was the optimum concentration recommended for cultivation of S. platensis (Celekli and Yavuzatmaca, 2009).
Table-2: Biomass and productivity of $S$. platensis at Zarrouk and goat manure media during the study.

\begin{tabular}{|c|c|c|c|c|c|}
\hline $\begin{array}{c}\text { Medium of } \\
\text { cultivation }\end{array}$ & $\begin{array}{c}\text { Initial dry } \\
\text { weight }(\mathbf{g} / \mathbf{L})\end{array}$ & $\begin{array}{c}\text { Dry weight on } \\
\text { day } \mathbf{( g / L )}\end{array}$ & $\begin{array}{c}\text { Dry weight } \\
\text { day on } \mathbf{1 4} \\
(\mathbf{g} / \mathbf{L})\end{array}$ & $\begin{array}{c}\text { Productivity of } \\
\text { the first 7 } \\
\text { days }(\mathrm{g} / \mathbf{L} / \mathbf{d a y})\end{array}$ & $\begin{array}{c}\text { Productivity } \\
\text { of the second } \\
\mathbf{7} \text { days } \\
(\mathrm{g} / \mathbf{L} / \mathbf{d a y})\end{array}$ \\
\hline Zarrouk & $0.193 \pm 0.071^{\mathrm{a}}$ & $1.284 \pm 0.191^{\mathrm{a}}$ & $2.431 \pm 0.113^{\mathrm{b}}$ & $0.156 \pm 0.021^{\mathrm{a}}$ & $0.164 \pm 0.016^{\mathrm{b}}$ \\
\hline $\begin{array}{c}25 \mathrm{~g} / \mathrm{L} \text { goat } \\
\text { manure }\end{array}$ & $0.187 \pm 0.064^{\mathrm{a}}$ & $1.185 \pm 0.146^{\mathrm{a}}$ & $2.082 \pm 0.096^{\mathrm{a}}$ & $0.143 \pm 0.009^{\mathrm{a}}$ & $0.128 \pm 0.011^{\mathrm{a}}$ \\
\hline $\begin{array}{c}50 \mathrm{~g} / \mathrm{L} \text { goat } \\
\text { manure }\end{array}$ & $0.176 \pm 0.057^{\mathrm{a}}$ & $1.271 \pm 0.087^{\mathrm{a}}$ & $2.341 \pm 0.154^{\mathrm{b}}$ & $0.156 \pm 0.015^{\mathrm{a}}$ & $0.153 \pm 0.012^{\mathrm{b}}$ \\
\hline $\begin{array}{c}75 \mathrm{~g} / \mathrm{L} \text { goat } \\
\text { manure }\end{array}$ & $0.212 \pm 0.049^{\mathrm{a}}$ & $1.317 \pm 0.173^{\mathrm{a}}$ & $2.425 \pm 0.097^{\mathrm{b}}$ & $0.158 \pm 0.019^{\mathrm{a}}$ & $0.158 \pm 0.014^{\mathrm{b}}$ \\
\hline $\begin{array}{c}100 \mathrm{~g} / \mathrm{L} \text { goat } \\
\text { manure }\end{array}$ & $0.198 \pm 0.053^{\mathrm{a}}$ & $1.328 \pm 0.129^{\mathrm{a}}$ & $2.397 \pm 0.186^{\mathrm{b}}$ & $0.161 \pm 0.012^{\mathrm{a}}$ & $0.153 \pm 0.009^{\mathrm{b}}$ \\
\hline
\end{tabular}

The values and standard deviation $( \pm)$ with different superscripts $\left({ }^{\mathrm{a}}\right.$ and $\left.{ }^{\mathrm{b}}\right)$ in same column are different significant $(\mathrm{p}<0.05)$.

\section{Nutrient composition in $S$. platensis biomass}

The composition of the main components of Spirulina biomass such as proteins, carbohydrates and lipids (Klinthong et al., 2015) as well as carotenoids, vitamins, and mineral salts depends on growth conditions (Koller et al., 2014; Hamed, 2016). Protein content in $S$. platensis biomass from 5 media at both the early stages and the end of cultivation are presented in Figure 2. At the early stages of cultivation, there is no significant $(\mathrm{P}>0.05)$ difference between protein content in $S$. platensis biomass from all concentration of goat manure and Zarrouk media. At the end stages, protein content in $S$. platensis biomass which cultivated from $50(59.03 \pm 4.31 \%), 75$ $(62.56 \pm 6.04 \%)$ and $100 \mathrm{~g} / \mathrm{L}(61.22 \pm 4.54 \%)$ goat manure and Zarrouk $(63.21 \pm 5.97 \%)$ media were significantly $(\mathrm{P}<0.05)$ higher than $25 \mathrm{~g} / \mathrm{L}$ $(47.35 \pm 5.16 \%)$. There was no significant $(\mathrm{p}>0.05)$ difference protein content in $S$. platensis biomass at the end of cultivation from 50,75 and $100 \mathrm{~g} / \mathrm{L}$ goat manure and Zarrouk media. From the medium $25 \mathrm{~g} / \mathrm{L}$ goat manure, there was a decrease in protein content in $S$. platensis biomass about $15.96 \%$ from $63.31 \pm 7.07 \%$ at the early stage to $47.35 \pm 5.16 \%$ at the end stage.

This study shows that the protein content in $S$. platensis biomass is influenced by the concentration of goat manure in media. Referring to the results of analysis of some mineral content in goat manure media (table 1), the low concentration of nitrogen especially nitrate may be the cause of the lower protein content in $S$. platensis biomass from goat manure 25 $\mathrm{g} / \mathrm{L}$ than other cultivations media in this study. 


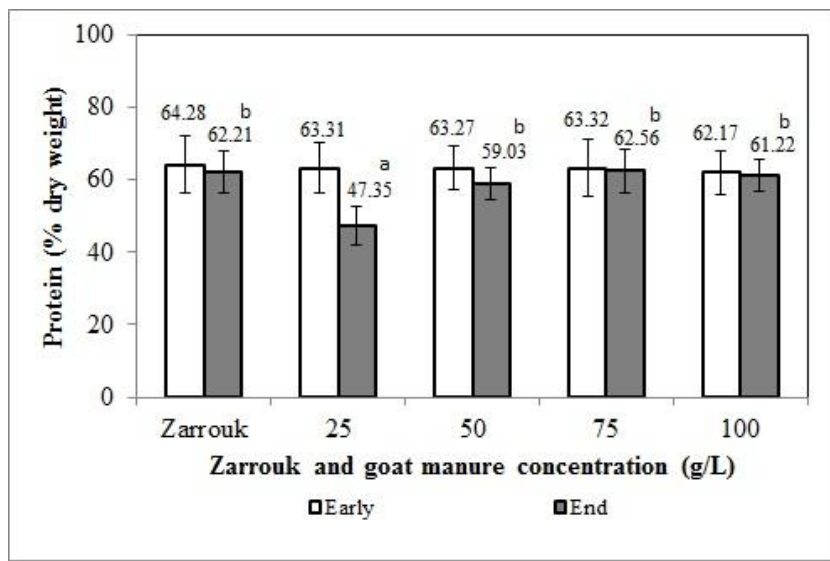

Figure-2: Protein content in S. platensisbiomass which was cultivated in Zarrouk and goat manure culture media. The values with different superscripts $\left({ }^{a}\right.$ and $\left.{ }^{b}\right)$ in same stage are different significant $(\mathbf{p}<0.05)$.

According to Inokuchi et al., (2002), the concentration of nitrate in cultivation media has an effect on the synthesis of proteins and nucleic acids. Nitrate also affects nitrogen assimilation and activity of various enzymes in S. platensis (Perez-Garcia et al., 2011). The protein content in $S$. platensis biomass from Zarrouk, 50, 75 and $100 \mathrm{~g} / \mathrm{L}$ media goat manure in this study is in the range of protein content in S. platensis biomass reported Gutiérrez-Salmeán et al. (2015) which ranges from 60 to $70 \%$ dry biomass weight. Nevertheless, differences in protein content in $S$. platensis biomass cultivated under different nutritional conditions have been reported by Marrez et al. (2014).

Lipid content in $S$. platensis biomass from 5 media at both the early stages and the end of cultivation are presented in figure 3 . At the early stages of cultivation, there is no significant difference between lipid content in S. platensis biomass from all concentration of goat manure and Zarrouk media. At the end stages, lipid content S. platensis biomass from Zarrouk media $(5.28 \pm 0.38 \%), \quad 50 \mathrm{~g} / \mathrm{L} \quad(5.31 \pm 1.27 \%), \quad 75 \mathrm{~g} / \mathrm{L}$ $(5.37 \pm 1.25 \%)$ and $100 \mathrm{~g} / \mathrm{L}(5.42 \pm 1.35 \%)$ goat manure were significantly $(\mathrm{P}<0.05)$ lower than $25 \mathrm{~g} / \mathrm{L}$ $(7.86 \pm 1.16 \%)$. From the medium of $25 \mathrm{~g} / \mathrm{L}$ of goat manure, the lipid content in $S$. platensis biomass increased about $2.55 \%$ from $5.31 \%$ at the early stage to $7.86 \%$ at the end stage. Referring to the results of the analysis of some mineral content in goat manure media (table 1), the low concentration of nitrogen especially nitrate and phosphorus may be the cause of higher lipid content in $S$. platensis biomass from goat manure $25 \mathrm{~g} / \mathrm{L}$ than other cultivation media in this study. According to some investigators, the concentration of nitrogen, phosphate and iron in cultivation media has an effect on the lipid content in the $S$. platensis biomass (Nyabuto et al. 2015; Liu et al., 2008). The low nitrogen concentration in cultivation media can increase lipid content in some microalgae biomass (Illman et al., 2000). Uslu et al. (2011) reported that 50 and $100 \%$ nitrogen deficiency in Spirulina increased total lipid ratio by 13.66 and $17.05 \%$ and reduced in protein of 53.5 and $5.6 \%$, respectively. The lipid content in Spirulina biomass around $5-10 \%$ of its dry weight varies with cultivation conditions and analytical methods (Gutiérrez-Salmeán et al., 2015). Several investigators reported lipid content in Spirulina biomass ranged from 6 to $15 \%$ (Xue et al., 2002; Colla et al., 2007; Promya et al., 2008; Madkour et al., 2012). Optimal concentration of lipid content in Spirulina biomass for food or feed has not been documented. Polyunsaturated fatty acids are considered as important fractions of Spirulina lipid biomass.

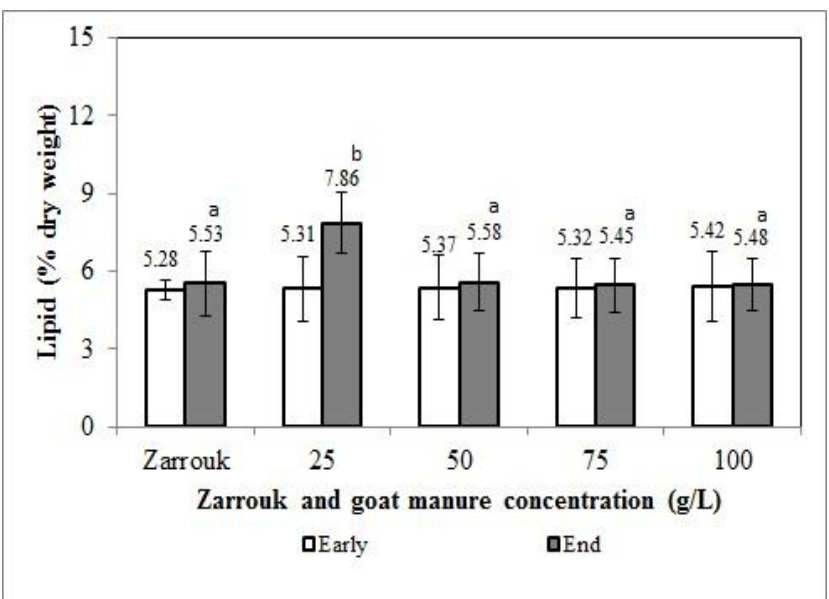

Figure-3: Lipid content in $S$. platensis biomass which was cultivated in Zarrouk and goat manure culture media. The values with different superscripts ( ${ }^{a}$ and $\left.{ }^{b}\right)$ in same stage are different significant $(p<0.05)$.

Carbohydrate content in S. platensis biomass from 5 media at both the early stages and the end of cultivation are presented in figure 4. At the early stages of cultivation, there is no significant difference between carbohydrate content in S. platensis biomass at all concentrations of goat manure and Zarrouk media. At the end stages, carbohydrate in S. platensis biomass from Zarrouk $(22.58 \pm 2.38 \%), \quad 50 \mathrm{~g} / \mathrm{L}$ 
$(21.67 \pm 2.25 \%), 75 \mathrm{~g} / \mathrm{L}(22.43 \pm 2.14 \%)$ and $100 \mathrm{~g} / \mathrm{L}$ $(22.67 \pm 2.38 \%)$ goat manure were significantly $(\mathrm{P}<0.05)$ lower than $25 \mathrm{~g} / \mathrm{L}(27.69 \pm 1.78 \%)$. From the medium of $25 \mathrm{~g} / \mathrm{L}$ of goat manure, the carbohydrate content in S. platensis biomass increased about $4.18 \%$ from $23.51 \%$ at the early stage to $27.69 \%$ at the end stage of cultivation. Referring to the results of analysis of some mineral content in goat manure media (table 1), low nitrogen especially nitrate and phosphorus may be the cause of higher carbohydrate content in $S$. platensis biomass from goat manure $25 \mathrm{~g} / \mathrm{L}$ than other cultivation media in this study. The carbohydrate content in $S$. platensis biomass is influenced by nitrogen concentration (Menegol et al., 2017).

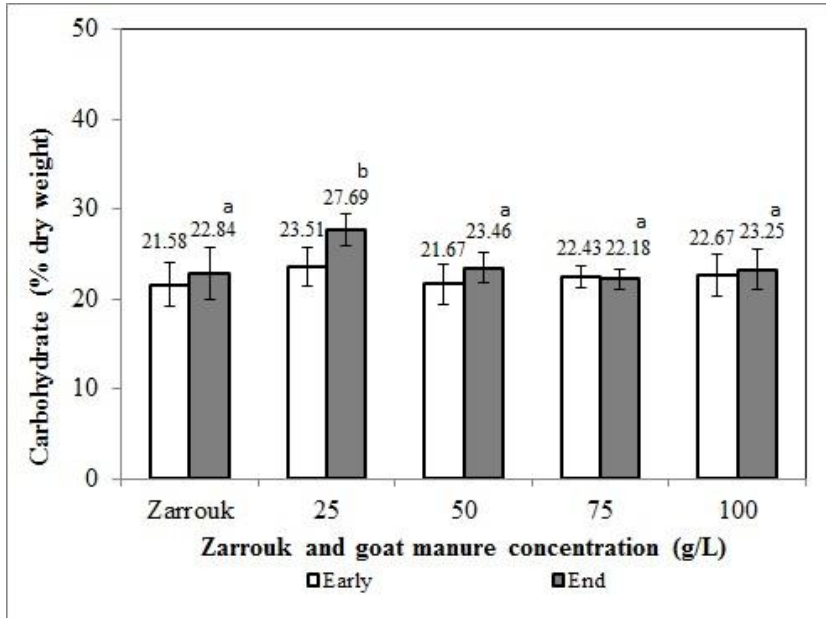

Figure-4: Carbohydrate content in $S$. platensis biomass which was cultivated in Zarrouk and goat manure culture media. The values with different superscripts ( ${ }^{a}$ and $\left.{ }^{b}\right)$ in same stage are different significant $(\mathbf{p}<0.05)$.

At low nitrogen concentrations in cultivation media, lipid and carbohydrate biosynthesis increases (Fan et al., 2012; Ho et al., 2012; Wang et al., 2014; Moraes et al., 2018) while protein synthesis decreases (Zhu et al., 2014). Markou et al. (2012) reported that the phosphorus concentration of $10 \mathrm{mg} / \mathrm{L}$ in the form of $\mathrm{K}_{2} \mathrm{HPO}_{4}$ in cultivation media could increase the carbohydrate content in $S$. platensis biomass. The carbohydrate content of $S$. platensis biomass is generally around 2-20\% (Vonshak, 2002). However, some researchers have reported an increase in carbohydrate content in $S$. platensis biomass. Increased carbohydrate content in S. platensis biomass can be caused by phosphorus deficiency in cultivation media (Dean et al., 2008; Cade-Menun and Paytan,
2010) or algal cell stress due to nitrogen deficiency cultivation media (Sassano et al., 2010).

Chlorophyll in $S$. platensis biomass from 5 media at both early stages and the end of cultivation are presented in figure 5. At the early stages of cultivation, there is no significant difference between chlorophyll content in $S$. platensis biomass from all concentration of goat manure and Zarrouk media. At the end stages, there was no significant $(\mathrm{P}>0.05)$ difference between chlorophyll content in $S$. platensis biomass from Zarrouk (1.65 $\pm 0.07 \%), 50 \mathrm{~g} / \mathrm{L}(1.62 \pm 0.09 \%), 75 \mathrm{~g} / \mathrm{L}$ $(1.65 \pm 0.08 \%)$ and $100 \mathrm{~g} / \mathrm{L} \quad(1.61 \pm 0.12 \%)$, but chlorophyll content in $S$. platensis biomass from Zarrouk and goat manure with 50, 75 and $100 \mathrm{~g} / \mathrm{L}$ concentration were significantly $(\mathrm{P}<0.05)$ higher than $25 \mathrm{~g} / \mathrm{L}(1.36 \pm 0.15 \%)$. In the $25 \mathrm{~g} / \mathrm{L}$ goat manure medium, the chlorophyll content in $S$. platensis biomass decrease about from $0.3 \%$ from $1.66 \%$ at the early stage to $1.36 \%$ at the end stage.

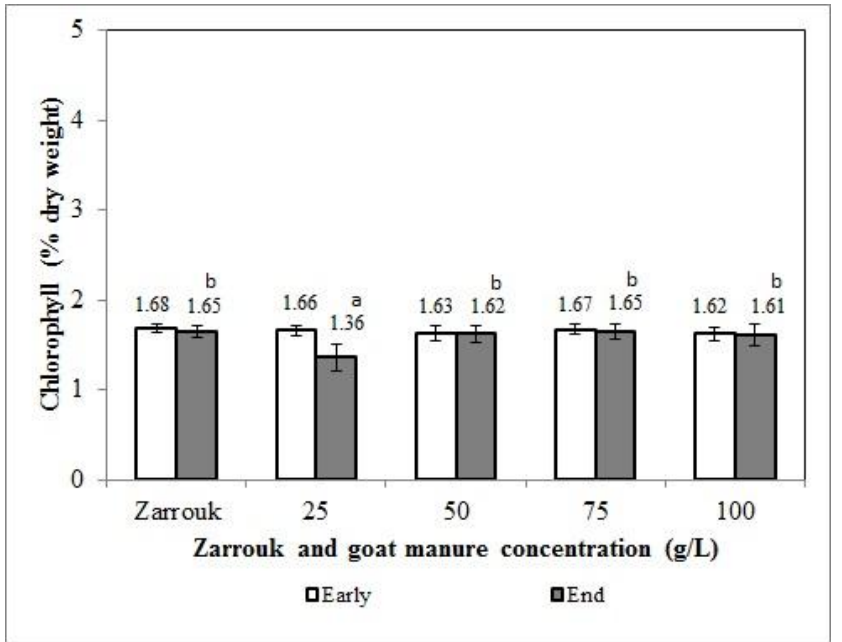

Figure-5: Chlorophyll content in S. platensis biomass which was cultivated in Zarrouk and goat manure culture media. The values with different superscripts $\left({ }^{a}\right.$ and ${ }^{b}$ ) in same stage are different significant $(\mathbf{p}<0.05)$.

According to the results of analysis of some mineral content in goat manure media (table 1), the low nitrogen content, especially nitrate, phosphorus and phosphate may be the cause of lower chlorophyll content in $S$. platensis biomass from goat manure 25 $\mathrm{g} / \mathrm{L}$ than the other cultivation media in this study. The chlorophyll content of microalgae is determined by the concentration of minerals and nitrogen in cultivation media (Daughtry et al., 2000). Furthermore, Esen and Ürek (2014) reported that nitrate concentrations of 10 
$\mathrm{mM}$ in the form of sodium nitrate were insufficient for pigment production algae. Some investigators have reported that low concentrations of nitrogen and phosphorus in cultivation media can inhibit photosynthesis, decrease protein and chlorophyll content and increase carbohydrate and lipid content in biomass S. platensis (George et al., 2014; Wykoff et al., 1998).

\section{Conclusion}

The present study demonstrated that goat manure can be used as a $S$. platensis cultivation medium. Goat manure can be a cheap alternative cultivation medium for Spirulina production. The optimal concentration of goat manure for $S$. platensis cultivation in this study was $75 \mathrm{~g} / \mathrm{L}$. The concentration of goat manure of less than $50 \mathrm{~g} / \mathrm{L}$ in cultivation media can cause a decrease in productivity and protein and chlorophyll content in Spirulina biomass because the concentration of nutrients, especially nitrogen and phosphorus is not enough to support the maximum growth of Spirulina.

\section{Acknowledgment}

The authors would like to thank the Head of the Biology Laboratory and The Dean of the Faculty of Mathematics and Natural Sciences, The University of PGRI Adi Buana Surabaya, Indonesia for providing research facilities.

\section{Disclaimer: None.}

Conflict of Interest: None.

Source of Funding: None.

\section{References}

Agwa OK, Ibe SN and Abu GO, 2012. Economically effective potential of Chlorella sp. for biomass and lipid production. J. Microbiol. Biotech. Res. 2(1):35-45.

Andrade MR and Costa JAV, 2009. Culture of microalga Spirulina platensis in alternative sources of nutrients. Ciênc. Agrotec. 32(5): 1551$1535 . \quad$ http://dx.doi.org/10.1590/S141370542008000500029.

Avila-Leon I, Matsudo MC, Sato S and Carvalho JCM, 2012. Arthospira platensis biomass with high protein content cultivated in continuous process using urea as nitrogen sources. J. Appl. Microbiol. 112(6):1084-94.
Association of Official Analytical Chemists (AOAC). 1990. Official Methods of Analysis. $15^{\text {th }}$ Ed., Association of Official Analytical Chemists. Washington, DC., USA.

Awodun MA, Omonijo LI and Ojeniyi SO, 2007. Effect of Goat Dung and NPK Fertilizer on Soil and Leaf Nutrient Content, Growth and Yield of Pepper. Int. J. Soil Sci. 2(2): 142-147. http://dx.doi.org/10.3923/ijss.2007.142.147

Belay A, 2002. Spirulina (Arthrospira) as a nutritional and therapeutic supplement in health management. JANA. 5(2): 27-48.

Cade-Menun BJ and Paytan A, 2010. Nutrient temperature and light stress alter phosphorus and carbon forms in culture-grown algae. Mar. Chem. 121(1-4): $27-36$. http://dx.doi.org/10.1016/j.marchem.2010.03.002

Canizares RO, Rivas L, Montes $\mathrm{C}$ and Dominguez AR, 1994. Aerated swine-wastewater treatment with K-Carrageenan-immobilized Spirulina maxima. Bioresour. Technol. 47(1): 89-91. https://doi.org/10.1016/0960-8524(94)90035-3

Celekli A and Yavuzatmaca M, 2009. Predictive modeling of biomass production by Spirulina platensis as function of nitrate and $\mathrm{NaCl}$ concentrations. Biores. Tech. 100: 1847-1851.

Colla LM, Reinehr CO, Carolina R and Jorge AVC. 2007. Production of biomass and nutraceutical compounds by Spirulina platensis under different temperature and nitrogen regimes. Bioresour. Technol. 98(7): 1489-1493. https://doi.org/10.1016/j.biortech.2005.09.030

Dammak M, Hadrich B, Miladi R, Barkallah M, Hentati F, Hachicha R, Laroche C, Michaud P, Fendri I and Abdelkafi S, 2017. Effects of nutritional conditions on growth and biochemical composition of Tetraselmis sp. Lipids Health Dis. 16: 41. http://dx.doi.org/10.1186/s12944-0160378-1

Danmaigoro O, Halilu AG and Izge AU, 2019. Growth and yield of direct seeded upland rice varieties as influenced by weed management and organic manure application. J. Res. Weed Sci. 2(2): 103114. https://dx.doi.org/10.26655/jrweedsci.2019.3.2

Daughtry CST, Walthall CL, Kim MS, Brown de Colstoun E and McMurtrey JE, 2000. Estimating corn leaf chlorophyll concentration from leaf and canopy reflectance. Remote Sens. Environ. 74(2):229-239. https://doi.org/10.1016/S00344257(00)00113-9 
Dean AP, Nicholson JM and Sigee DC, 2008. Impact of phosphorus quota and growth phase on carbon allocation in Chlamydomonas reinhardtii: an FTIR microspectroscopy study. Eur. J. Phycol. 43(4):

345-354. http://dx.doi.org/10.1080/09670260801979287

Esen M and Ürek RÖ, 2014. Nitrate and iron nutrition effects on some nitrate assimilation enzymes and metabolites in Spirulina platensis. Turk. J. Biol. 38: 690-700. http://dx.doi.org/10.3906/biy-140537

Estrada JEP, Bescos PB and Fresno AMV, 2001. Anti oxidant activity of different fractions of Spirulina platensis protean extract. Il Farmaco. 56: $497-$ 500.

Fan J, Yan C, Andre C, Shanklin J, Schwender J and $\mathrm{Xu} \mathrm{C}, 2012$. Oil accumulation is controlled by carbon precursor supply for fatty acid synthesis in Chlamydomonas reinhardtii. Plant Cell Physiol. 53(8):1380-1390. http://dx.doi.org/10.1093/pcp/pcs082

George B, Pancha I, Desai C, Chokshi K, Paliwal C, Ghosh T and Mishra S, 2014. Effects of different media composition, light intensity and photoperiod on morphology and physiology of freshwater microalgae Ankistrodesmus falcatus A potential strain for bio-fuel production. Bioresour Technol. 2014; 171: $367-$ 374.

http://dx.doi.org/10.1016/j.biortech.2014.08.086

Gutiérrez-Salmeán G, Fabila-Castillo L and Chamorro-Cevallos G. 2015. Nutritional and toxicological aspects of Spirulina (Arthrospira). Nutrición Hospitalaria. 32(1): 34-40. http://dx.doi.org/10.3305/nh.2015.32.1.9001.

Hamed I, 2016. The Evolution and Versatility of Microalgal Biotechnology: A Review. Compar. Rev. Food Sci. Food Safet. 15: 1104-1123. https://doi.org/10.1111/1541-4337.12227

Ho SH, Chen C and Chang JS, 2012. Effect of light intensity and nitrogen starvation on $\mathrm{CO}_{2}$ fixation and lipid/carbohydrate production of an indigenous microalga Scenedesmus obliquus CNW-N. Bioresour. Technol. 113: 244252.

http://dx.doi.org/10.1016/j.biortech.2011.11.133

Holman BWB and Malau-Aduli AEO, 2013.Spirulina as a livestock supplement and animal feed. Review Article. J. Anim. Physiol. Anim. Nutr. 97: 615-623.

Illman AM, Scragg AH and Shales SW, 2000. Increase in Chlorella strains calorific values when grown in low nitrogen medium. Enzyme Microb. Technol. 27: 631-635.

Inokuchi R, Kuma K, Miyata T and Okada M, 2002. Nitrogen-assimilating enzymes in land plants and algae: phylogenic and physiological perspectives. Physiol. Plant. 116: 1-11.

Iyoyo GD, Guocheng D and Chen J, 2010. Poultry manure Digestate Enhancement of Chlorella vulgaris Biomass under Mixotrophic Condition for Biofuel Production. J. Microbial. Biochem. Technol. $\quad 2$ : $051-057$. http://dx.doi.org/10.4172/1948-5948.1000023

Jeffrey SW and Humphrey GF, 1975. New spectrophotometric equations for determining chlorophyll a, b c1 and c2 in higher plants, algae and natural phytoplankton. Biochemie und Physiologie der Pflanzen. 167: 191-194.

Kerswell AP, 2006. Global biodiversity patterns of benthic marine algae. Ecol. 87(10): 2479-2488.

Kinosraj K, Man KL, Xin BT, Yoshimitsu U, Jun WL, Choon GK and Keat TL, 2016. Cultivation of Chlorella vulgaris Using Plant-based and Animal waste-based Compost: A Comparison Study. Procedia Engin. 8(2016): 679-686. http://dx.doi.org/10.1016/j.proeng.2016.06.551

Klinthong W, Yang YH, Huang CH and Tan CS. 2015. A Review: Microalgae and Their Applications in $\mathrm{CO}_{2}$ Capture and Renewable Energy. Aerosol Air Qual. Res. 15: 712-742. http://dx.doi.org/10.4209/aaqr.2014.11.0299

Koller M, Muhr A and Braunegg G, 2014. Microalgae as versatile cellular factories for valued products. Algal Res. 6: 52-63.

Li B, Chu X, Gao M and Li W, 2010. Apoptotic mechanism of MCF-7 breast cells in vivo and in vitro induced by photodynamic therapy with $\mathrm{C}$ phycocyanin. Acta Biochim. Biophys. Sin. 42: 80-89.

Liu ZY, Wang GC and Zhou BC, 2008. Effect of iron on growth and lipid accumulation in Chlorella vulgaris, Bioresour. Technol. 99: 4717- 4722.

Markou G, Chatzipavlidis I and Georgakakis D, 2012. Effects of phosphorus concentration and light intensity on the biomass composition of Arthrospira (Spirulina) platensis. World J. Microbiol. Biotechnol. 28: 2661-2670. http://dx.doi.org/10.1007/s11274-012-1076-4

Madkour FF, Kamil AW and Nasr HS. 2012. Production and nutritive value of Spirulinaplatensis in reduced cost media. The 
Egypt J. Aqua. Res. 38(1): 51-57. https://doi.org/10.1016/j.ejar.2012.09.003

Marrez DA, Naguib MM, SultanYY, Daw ZY and Higazy AM, 2014. Evaluation of chemical composition for Spirulina platensis in different culture media. Res. J. Pharmacol. Biol Chem. Sci. 4: 1161-1171.

Menegol T, Diprat AB, Rodrigues E and Rech R, 2017. Effect of temperature and nitrogen concentration on biomass composition of Heterochlorella luteoviridis. Food Sci. Technol. Campinas. 37(Special issue): 28-37. http://dx.doi.org/10.1590/1678-457x.13417.

Mezzomo N, Saggirato AG, Siebert R, Tatsch PO, Lago MC, Hemkemeier M, Costa JAV, Bertolin TE and Colla LM, 2010. Cultivation of microalgae Spirulina platensis from biological treatment of swine wastewater. J. Technol. 1: 173$178 . \quad$ http://dx.doi.org/10.1590/S010120612010000100026.

Mnkeni PNS and Austin LM, 2009. Fertiliser value of human manure from pilot urine-diversion toilets.Water SA. 1: 133-138.

Moraes CC, Sala L, Cerveira GP and Kalil SJ, 2011. C-Phycocyanin Extraction from Spirulina platensis Wet Biomass. Braz. J. Chem. Eng. 1: 4549.

Moraes L, da Rosa GM, de Souza MDRAZ and Vieira Costa JAV, 2018. Carbon Dioxide Biofixation and Production of Spirulina sp. LEB 18 Biomass with Different Concentrations of $\mathrm{NaNO}_{3}$ and NaCl. Braz. Arch. Biol. Technol. 61: e18150711. http://dx.doi.org/10.1590/1678-43242018150711

Muhling M, Belay A and Whitton BA, 2005. Variationin fatty acid composition of Arthrospira (Spirulina) strains. J. Appl. Phycol. 17: 137-146.

Nyabuto DK, Cao K, Mariga AM, Kibue GW, He M and Wang C, 2015. Growth performance and biochemical analysis of the genus Spirulina under different physical and chemical environmental factors. Afr. J. Agric. Res. 36: 3614-3624. http://dx.doi.org/10.5897/AJAR2015.10210.

Olguin EJ, Galicia S, Angulo-Guerrero $\mathrm{O}$ and Hernandez E, 2001. The effect of low light flux and nitrogen deficiency on the chemical composition of Spirulina sp. (Arthrospire) grown on digested pig waste. Bioresour. Tech. 77: 19-24.

Omisore KO, Ojo VOA, Muraina TO, Jamiu SA, Popoola KO and Dele PA, 2018. Effect of manure and harvesting age on physical and chemical properties of pennisetum hybrid silage. Slovak J. Anim. Sci. 51(2): 79-85.

Perez-Garcia O, Escalante FME, Bashan LE and Bashan Y, 2011. Heterotrophic cultures of microalgae: metabolism and potential products. Water Res. 45: 11-36.

Pleonsil P, Soogarun S and Suwanwong Y, 2013. Anti-oxidant activity of holo- and apo-cphycocyanin and their protective effects on human erythrocytes. Int. J. Biol. Macromol. 60: 393-8.

Powell JM, Fernandez-Rivera S and Hofs S, 1994. Effects of sheep diet on nutrient cycling in mixed farming systems semi-arid West Africa. Agric. Ecosyst. Environ. 48(3): 263-271.

Promya J, Traichaiyaporn S and Deming R, 2008. Phytoremediation of kitchen wastewater by Spirulinaplatensis (Nordstedt) Geiteler: pigment content, production variable cost and nutritional value. Maejo Int. J. Sci. Technol. 2(1): 59-171.

Sánchez M, Caltillo BJ, Rozo C and Rodriquez I, 2003. Spirulina (Arthrospira): an edible microorganism. A Rev. Universitas Scentiarum. 1: 1-16.

Sassano CEN, Gioielli LA, Ferreira LS, Rodrigues MS, Sato S, Converti A and Carvalho, JCM, 2010. Evaluation of the composition of continuouslycultivated Arthrospira (Spirulina) platensis using ammonium chloride as nitrogen source. Biomass Bioenerg. 34(12): 1732-1738. http://dx.doi.org/10.1016/j.biombioe.2010.07.002

Sherwood AR, Kurihara A, Conklin KY, Sauvage T and Presting GG, 2010. The Hawaiian Rhodophyta Biodiversity Survey (2006-2010) a summary of principal findings. BMC Plant Biol. 10(1): 258.

Smith KA and Frost JP, 2000. Nitrogen excretion by farm livestock with respect to land spreading requirements and controlling nitrogen losses to ground and surface waters. Part 1: cattle and sheep. Bioresour. Tech. 71(2): 173-181.

Tennakoon NA and Bandara SDH, 2003. Nutrient content of some locally available organic materials and their potential as alternative sources of nutrients for coconut. Cocos. 15: 23-30.

Thangam R, Suresh V, Asenath PW, Rajkumar M, Senthilkumar N, Gunasekaran P, Rengasamy R, Anbazhagan C, Kaveri K and Kannan S, 2013. CPhycocyanin from Oscillatoria tenuis exhibited an antioxidant and in vitro antiproliferative activity through induction of apoptosis and G0/G1 cell cycle arrest. Food Chem. 140: 262-272. 


\section{Tatang Sopandi et al.}

Uslu LH, Işik O, Koç K and Göksan T, 2011. The effects of nitrogen deficiencies on the lipid and protein contents of Spirulina platensis. Afr. J. Biotechnol. 3: 386-389. http://dx.doi.org/10.5897/AJB10.1547

Vonshak A, 2002. Spirulina platensis (Arthrospira): physiology, cell biology and biotechnology. Taylor \& Francis, London.

Walkey C and Black CA, 1965. Organic carbon. In Methods of soil analysis ed. Black, C.A. pp. 1372-1375. Madison, WI: American Society of Agronomy.

Wang CY, Wang X, Wang Y, Zhou T, Bai Y, Li YC and Huang B, 2012. Photosensitization of phycocyanin extracted from Microcystis in human hepatocellular carcinoma cells: implication of mitochondria-dependent apoptosis. J. Photochem. Photobiol. B, Biol. 117: 70-79.

Wang HT, Yao CH, Ai JN, Cao XP, Xue S and Wang $\mathrm{W}, 2014$. Identification of carbohydrates as the major carbon sink of the marine microalga Isochrysis zhangjiangensis (Haptophyta) and optimization of its productivity by nitrogen manipulation. Bioresour. Tech. 171: 298304. http://dx.doi.org/10.1016/j.biortech.2014.08 .090 .

Wykoff DD, Davies JP, Melis A and Grossman AR, 1998. The regulation of photosynthetic electron transport during nutrient deprivation in Chlamydomonas reinhardtii. Plant Physiol. 117:129-139. http://dx.doi.org/10.1104/pp.117.1.129

Xin L, Hong-Ying H, Ke G and Ying-Xue S, 2010. Effects of different nitrogen and phosphorus concentrations on the growth, nutrient uptake, and lipid accumulation of a freshwater microalga Scenedesmus sp. Bioresour. Technol. 101(14): 5494-5500.
Xue C, Hu Y, Saito H, Zhang Z, Li Z, Cai Y, Ou C and Lin H, 2002. Imbs A.B. Molecular species composition of glycolipids from Sprirulina platensis. Food Chem. 77: 9-13.

Yap PY, Jain A and Trau D, 2018. Determination of biomass in Spirulina cultures by photopette. Life Science Application Note 050. Version 1: 1-3.

Zarrouk C, 1966. Contribution a l'etude d'une cyanophycee. Influence de divers facteurs physiques et chimiques sur la croissance et la photosynthese de Spirulina maxima (Setch. et Gardner). Geitler [Ph.D. thesis], University of Paris, Paris, France, 1966.

Zhu S, Huang W, Xu J, Wang Z, Xu J and Yuan Z, 2014. Metabolic changes of starch and lipid triggered by nitrogen starvation in the microalga Chlorella zofingiensis. Bioresour. Technol. 152: 292-298. http://dx.doi.org/10.1016/j.biortech.2013.10.092.

Zhu C, Ling Q, Cai Z, Wang Y, Zhang Y, Hoffmann PR, Zheng W, Zhou T and Huang Z, 2016. Selenium-Containing Phycocyanin from SeEnriched Spirulina platensis Reduces Inflammation in Dextran Sulfate Sodium-Induced Colitis by Inhibiting NF-kappa B Activation. J. Agric. Food Chem. 64: 5060-5070.

\section{Contribution of Authors}

Sopandi T: Conducted research activities, cultivated and observed the development of daily S. platensis biomass, helped in data collection and analysis and manuscript writing

Rohmah S: Collected and analysed data and manuscript write up Agustina SAT: Collected and analysed data and manuscript write up 